PACS: 52.35.Mw, 73.20.Mf, 74.72.-h

UDC: $535.42,537.8$

\title{
Modification of transfer-matrix method for electromagnetic waves in layered superconductor in presence of dc magnetic field
}

\author{
N. Kvitka ${ }^{1}$, T. Rokhmanova ${ }^{2,3}$, S. S. Apostolov ${ }^{1,2}$ \\ 1 V. N. Karazin Kharkiv National University, 4 Svobody Sq., 61022 Kharkiv, Ukraine \\ 2 O.Ya. Usikov Institute for Radiophysics and Electronics NASU, 12 Ac. Proskura st., 61085 Kharkiv, Ukraine \\ 3 Departamento de Fisica - CIOyN, Universidad de Murcia, Murcia 30.071, Spain \\ rokhmanova@ieee.org
}

ORCID: 0000-0002-9757-3731

DOI:10.26565/2222-5617-2019-31-06

In the present paper, we modify the transfer-matrix method to study the dissipation-free transition of electromagnetic waves of terahertz range through a plate of layered superconductor embedded in the dielectric environment in the presence of external direct current (dc) magnetic field.

In this work, we consider TM-polarized electromagnetic waves. The setup is arranged in such a way that the dielectric and superconducting layers in the plate are perpendicular to its interface, and the external magnetic field is directed along the plate and parallel to the layers. We consider the case of a weak external dc field at which magnetic vortices do not penetrate the plate.

Due to the nonlinearity of the Josephson plasma formed in the layered superconductor, the dc magnetic field penetrates nonuniformly into the plate and affects the electromagnetic wave. Hence, the magnitude of the external dc magnetic field can be used as a variable parameter to tune various phenomena associated with the propagation of an electromagnetic waves in layered superconductors.

In the presence of the external homogeneous dc magnetic field, linear electromagnetic waves in the layered superconductor turn out to be non-exponential. Therefore we cannot directly apply the transfer matrix method, in which the amplitudes of the corresponding exponents are compared. However, in the present paper, it is shown that for a sufficiently thick plate, the matrices describing the wave transfer through the plate can be introduced. The analytical expressions for these matrices are derived explicitly in terms of special Legendre functions. The obtained transfer-matrices can be used for the further study of the wave transfer through the layered superconductor in the presence of an external dc magnetic field.

Keywords: layered superconductor, transfer-matrix method, special Legendre functions.

\section{Модифікація методу трансфер-матриць для електромагнітних хвиль у шаруватому надпровіднику за наявності постійного магнітного поля}

\author{
Н. Квітка, Т. Рохманова, С.С. Апостолов \\ 1 Харківський національний університет імені В.Н. Каразіна, м. Свободи 4, 61022, Харків, Украӥна \\ 2 Інститут радіофізики та електроніки ім. О.Я. Усикова НАН Украйни, вул. Проскура 12, 61085 Харків, Украйна \\ 3 Departamento de Fisica - CIOyN, Universidad de Murcia, Murcia 30.071, Spain
}

У даній статті ми модифікуємо метод трансфер-матриць для вивчення бездисипативного проходження електромагнітних хвиль терагерцевого діапазону через пластину шаруватого надпровідника, поміщеного в діелектричну середу, в присутності зовнішнього магнітного поля постійного струму.

В роботі ми розглядаємо ТМ-поляризовані електромагнітні хвилі. Пластина розташована таким чином, що шари діелектрика і надпровідника перпендикулярні межі розділу, а зовнішнє магнітне поле направлено вздовж пластини, паралельно шарам. Ми розглядаємо випадок слабкого зовнішнього магнітного поля, при якому магнітні вихори не проникають в пластину.

Внаслідок нелінійності джозефсонівської плазми, що формується в шаруватому надпровіднику, магнітне поле постійного струму нерівномірно проникає в пластину і впливає на електромагнітну хвилю. Тиким чином, величина зовнішнього магнітного поля постійного струму може бути використана в якості змінного параметра для управління різними явищами, пов'язаними з поширенням електромагнітних хвиль в шаруватих надпровідниках.

За наявності зовнішнього постійного однорідного магнітного поля лінійні електромагнітні хвилі в шаруватому надпровіднику виявляються неекспонеціальними. Тому ми не можемо безпосередньо застосувати метод трансфер-матриць, в якому зв'язуються амплітуди при відповідних експонентах. Незважаючи на це, в даній теоретичній роботі показано, що для досить товстої пластини можна ввести матриці, які описують проходження хвилі через пластину. Аналітичні вирази для цих матриць отримані в явному вигляді в термінах спеціальних функцій Лежандра. Отримані трансфер-матриці можуть бути використані для подальшого вивчення проходження електромагнітних хвиль через шаруватий надпровідник за наявності зовнішнього магнітного поля постійного струму.

Ключові слова: шаруватий надпровідник, метод трансфер-матриць, спеціальні функції Лежандра. 


\title{
Модификация метода трансфер-матриц для электромагнитных волн в слоистых сверхпроводниках в присутствии постоянного магнитного поля
}

\author{
Н. Квитка, Т. Рохманова, С.С. Апостолов \\ 1 Харьковский национальный университет имени В.Н. Каразина, м. Свободы 4, 61022, Харьков, Украина \\ 2 Институт радиофизики и электроники им. О.Я. Усикова НАН Украины, ул. Проскура 12, 61085 Харьков, Украина \\ 3 Departamento de Fisica - CIOyN, Universidad de Murcia, Murcia 30.071, Spain
}

В данной статье мы модифицируем метод трансфер-матриц для изучения бездиссипативного прохождения электромагнитных волн терагерцового диапазона через пластину слоистого сверхпроводника, помещенного в диэлектрическую среду, в присутствии внешнего магнитного поля постоянного тока.

В работе мы рассматриваем ТМ-поляризованные электромагнитные волны. Пластина расположена таким образом, что слои диэлектрика и сверхпроводника перпендикулярны границе раздела, а внешнее магнитное поле направлено вдоль пластины, параллельно слоям. Мы рассматриваем случай слабого внешнего магнитного поля, при котором магнитные вихри не проникают в пластину.

Вследствие нелинейости джозефсоновской плазмы, которая формируется в слоистом сверхпроводнике, магнитное поле постоянного тока неравномерно проникает в пластину и влияет на электромагнитную волну. Таким образом, величина внешнего магнитного поля постоянного тока может быть использована в качестве изменяемого параметра для управления различными явлениями, связанными с распространением электромагнитных волн в слоистых сверхпроводниках.

В присутствие внешнего постоянного однородного магнитного поля линейные электромагнитные волны в слоистом сверхпроводнике оказываются неэкспонециальными. Поэтому мы не можем непосредственно применить метод трансферматриц, в котором связываются амплитуды при соответствующих экспонентах. Несмотря на это, в данной теоретической работе показано, что для достаточно толстой пластины можно ввести матрицы, описывающие прохождение волны через пластину. Аналитические выражения для этих матриц получены в явном виде в терминах специальных функций Лежандра. Полученные трансфер-матрицы могут быть использованы для дальнейшего изучения прохождения электромагнитных волн через слоистый сверхпроводник в присутствие внешнего магнитного поля постоянного тока.

Ключевые слова: слоистый сверхпроводник, метод трансфер-матриц, специальные функции Лежандра.

\section{Introduction}

Layered superconductors are periodic structures that consist of thin alternating superconducting and insulating layers. Natural crystals $\mathrm{Bi}_{2} \mathrm{Sr}_{2} \mathrm{CaCu}_{2} \mathrm{O}_{8+\delta}$ or artificially grown compounds $\mathrm{NbAl}-\mathrm{AlO}_{x} / \mathrm{Nb}$ are examples of such materials. The superconducting layers form array of intrinsic Josephson junctions [1,2] and determine unusual strong anisotropy and nonlinearity of current flow. Therefore, the various non-trivial electromagnetic phenomena are predicted for layered superconductors $[3,4,5]$. Also, these materials are of particular interest due to possibility of flexible tuning their electromagnetic properties by an external direct current (dc) magnetic field [6,7]. The additional interest is related to the operating frequencies of the Josephson plasma waves that are of terahertz $(\mathrm{THz})$ range. By present, there is still a gap in controllable and high-power THz-devices, which are, meanwhile, considered to be promising for many areas starting from basic science to medicine or homeland security $[8,9]$.

To study the transfer of electromagnetic waves it is convenient to use the transfer-matrix method (see, e.g., book [10]). In the absence of dc magnetic field, the electromagnetic properties of the layered superconductor can be described by the effective permittivity tensor [11], and, therefore, the transfer-matrix method can be directly applied (see, e.g., the recent paper [4]). However, in the presence of an external dc magnetic field, the problem becomes more complicated because the electromagnetic field inside the plate is described not by harmonic (exponential) functions, but by special Legendre functions [6].

In this paper, we modify the transfer-matrix method for the electromagnetic wave propagation through a plate of layered superconductor in the presence of an external dc magnetic field and calculate the corresponding transfer-matrices.

\section{Problem Formulation}

We study a dissipation-free propagation of an electromagnetic wave through the system that consists of a layered superconductor plate of thickness $s$ placed in the dielectric environment as shown in Fig.1. Dielectric and superconducting layers are considered perpendicular to the interface. The coordinate system is chosen in such a way that the $x$-axis is directed perpendicular to the plate, the $z$-axis is orthogonal to the superconducting layers. The external dc magnetic field $\vec{H}_{0}$ is supposed to be directed parallel to the plate and to the layers, i.e. along the $y$-axis.

We consider TM-polarized wave. In the chosen coordinate system, its electric $\vec{E}(x, y, z, t)$ and magnetic $\vec{H}(x, y, z, t)$ components can be written as follows:

$$
\begin{aligned}
& \vec{E}(x, y, z, t)=\left\{E_{x}(x), 0, E_{z}(x)\right\} \exp \left(-i \omega t+i k_{z} z\right), \\
& \vec{H}(x, y, z, t)=\left\{0, H_{y}(x), 0\right\} \exp \left(-i \omega t+i k_{z} z\right),
\end{aligned}
$$


where $\omega$ is the wave frequency, $k_{z}$ is $z$-projection of the wave vector.

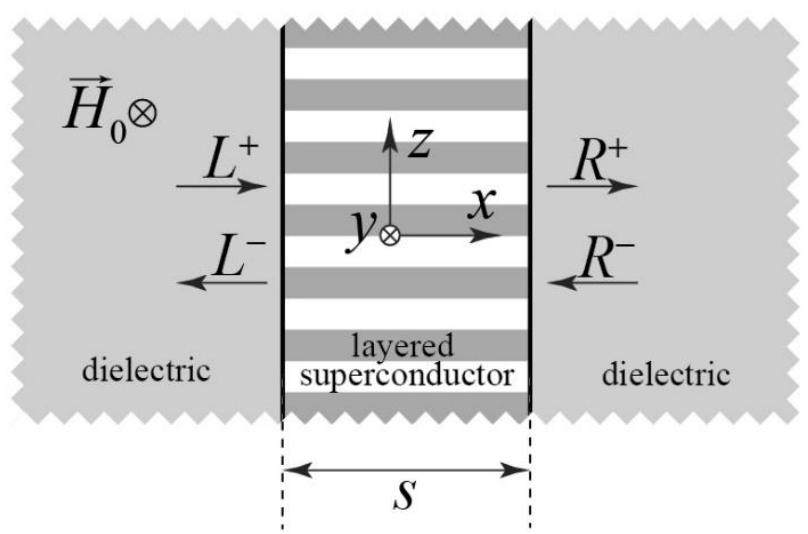

Fig. 1. Geometry of the problem, where $L^{+}$and $R^{-}$are the amplitudes of the electromagnetic waves incident onto the plate from the left and right, respectively, while $L^{-}$and $R^{+}$ are the amplitudes of electromagnetic waves running away from the left and right, respectively.

It is worth noting that the plate is supposed to be sufficiently thick:

$$
\exp \left(s / \lambda_{c}\right) \gg 1
$$

where $\lambda_{c}$ is the London penetration depth along the layers of superconductor. On this assumption, the $\mathrm{dc}$ magnetic field deeply inside the layered superconductor is absent. Also, we assume that the external magnetic field magnitude is less than the critical value $H_{c}$ :

$$
H_{0}<H_{c}=\frac{\Phi_{0}}{\pi d \lambda_{c}}
$$

where $\Phi_{0}=\pi \hbar c / e$ is the magnetic flux quantum, $c$ is the speed of light, $e$ is the elementary charge, $\hbar$ is Planck's constant, and $d$ is the thickness of the insulating layers.

\section{Main Equations for the Electromagnetic Field}

The expressions for the electromagnetic field components in a dielectric medium can be obtained from the system of Maxwell's equations. At the left and right interfaces, respectively, for magnetic components we have:

$$
\begin{aligned}
& H_{y}^{L}(x)=L^{+} e^{i k_{d}(x+s / 2)}+L^{-} e^{-i k_{d}(x+s / 2)}, \\
& H_{y}^{R}(x)=R^{+} e^{i k_{d}(x-s / 2)}+R^{-} e^{-i k_{d}(x-s / 2)},
\end{aligned}
$$

where $k_{d}$ is the $x$-projection of the wave vector of the incident wave:

$$
k_{d}=\sqrt{\varepsilon_{d} \omega^{2} / c^{2}-k_{z}^{2}}
$$

where $\varepsilon_{d}$ is the dielectric permittivity.

For the corresponding electric field components, we have:

$$
\begin{aligned}
& E_{z}^{L}(x)=-\frac{k_{d} c}{\varepsilon_{a} \omega}\left[L^{+} e^{i k_{d}(x+s / 2)}-L^{-} e^{-i k_{d}(x+s / 2)}\right], \\
& E_{z}^{R}(x)=-\frac{k_{d} c}{\varepsilon_{a} \omega}\left[R^{+} e^{i k_{d}(x-s / 2)}-R^{-} e^{-i k_{d}(x-s / 2)}\right] .
\end{aligned}
$$

The field inside the plate $(-s / 2<x<s / 2)$ is described by the interlayer phase difference $\varphi(x, z, t)$, which obeys the coupled sine-Gordon equations [3]. For the wavelengths that are greater than the thickness $d$ (i.e. in the continuous limit), it can be represented as follows:

$$
\left(1-\lambda_{a b}^{2} \frac{\partial^{2}}{\partial z^{2}}\right)\left[\frac{1}{\omega_{J}^{2}} \frac{\partial^{2} \varphi}{\partial t^{2}}+\sin \varphi\right]-\lambda_{c}^{2} \frac{\partial^{2} \varphi}{\partial x^{2}}=0,
$$

where $\lambda_{a b}$ is the London penetration depth across the layers, $\omega_{J}=\sqrt{8 \pi e d J_{c} / \hbar \varepsilon_{s}}$ is the Josephson plasma frequency, $\varepsilon_{s}$ is the dielectric constant of the insulator layers in the plate, and $J_{c}$ is the maximum density of the Josephson current.

On assumption (2), in the presence of the dc magnetic field and linear electromagnetic wave this phase difference can be presented as [6]:

$$
\varphi(\xi, z, t)=\varphi_{s t}^{+}(\xi)+\varphi_{s t}^{-}(\xi)+\varphi_{w}(\xi, z, t),
$$

where $\xi=x / \lambda_{c}$ is the normalized $x$-coordinate, and

$$
\varphi_{s t}^{ \pm}(\xi)=\mp 4 \arctan \left[\exp \left(\xi_{0} \pm \xi\right)\right]
$$

are static solutions of the sine-Gordon equation (6) that can be considered as the two virtual magnetic vortices which partly penetrate into the plate from both sides, and

$$
\varphi_{w}(\xi, z, t)=f(\xi) \exp \left(i k_{z} z-i \omega t\right)
$$

is a small wave additive induced by the electromagnetic wave with amplitude $f(\xi)$. In expression (8) parameter $\xi_{0}$ determines the positions of the vortices, 


$$
\xi_{0}=\delta+\operatorname{arccosh}\left(h_{0}^{-1}\right), \quad h_{0}=\frac{H_{0}}{H_{c}}, \quad \delta=s / 2 \lambda_{c} .
$$

The tangential electromagnetic field components in the layered superconductor plate [12]:

$$
\begin{aligned}
& E_{z}^{s}(\xi)=-H_{c} \frac{i \Omega}{\sqrt{\varepsilon_{s}}} f(\xi), \\
& H_{y}^{s}(\xi)=\frac{H_{c}}{1+\kappa_{z}^{2} /\left(1-\Omega^{2} / \gamma^{2}\right)} f^{\prime}(\xi),
\end{aligned}
$$

where $\Omega=\omega / \omega_{J}$ is the normalized frequency, $\kappa_{z}=k_{z} \lambda_{a b}$ is the normalized $z$-projection of the wave vector, and $\gamma=\lambda_{c} / \lambda_{a b}$ is the anisotropy parameter.

By substituting the expression (7) for the interlayer phase difference $\varphi$ into (6), we can obtain the following equation for the amplitude $f(\xi)$ of the wave additive $\varphi_{w}(\xi, z, t)$ :

$$
\frac{f^{\prime \prime}(\xi)}{\kappa_{s}^{2}}+[1-u(\xi)] f(\xi)=0,
$$

where

$$
\begin{gathered}
\kappa_{s}^{2}=\left(\Omega^{2}-1\right)\left(1+\frac{\kappa_{z}^{2}}{1-\Omega^{2} / \gamma^{2}}\right), \\
u(\xi)=\frac{1}{1-\Omega^{2}}\left[\frac{2}{\cosh ^{2}\left(\xi_{0}-\xi\right)}+\frac{2}{\cosh ^{2}\left(\xi_{0}+\xi\right)}\right] .
\end{gathered}
$$

In Eq. (12) the first additive corresponds to $\varphi_{s t}^{+}(\xi)$ and the second is related to $\varphi_{s t}^{-}(\xi)$.

First, we construct the solution for the right and left part of the plate independently. The interaction between magnetic vortices from the opposite sides can be neglected due to the assumption (2), then we neglect the first or second component with cosh in the expression (12). Then the solution of Eq. (11) can be found in terms of associated Legendre functions [13]. We present the solution in the form of superposition for the right half of the plate:

$$
f_{R}(\xi)=C^{+} f_{+}(\xi)+C^{-} f_{-}(\xi)
$$

and for the left one:

$$
f_{L}(\xi)=\tilde{C}^{+} f_{+}(-\xi)+\tilde{C}^{-} f_{-}(-\xi)
$$

where

$$
\begin{aligned}
f_{ \pm}(\xi) & =\frac{P_{v}^{\mp \mu}\left[\tanh \left(\xi_{0}-\xi\right)\right]}{\left.\frac{\partial}{\partial \xi} P_{v}^{\mp \mu}\left[\tanh \left(\xi_{0}-\xi\right)\right]\right|_{\xi=0}} \approx \\
& \approx \frac{P_{v}^{\mp \mu}\left[\tanh \left(\xi_{0}-\xi\right)\right]}{ \pm \mu K_{ \pm} \exp (\mp \mu \delta)},
\end{aligned}
$$

with $P_{v}^{\mu}[z]$ being the associated Legendre functions, and

$$
\begin{aligned}
2 v+1 & =\sqrt{8\left(\Omega^{2}-1\right)^{-1} \kappa_{s}^{2}+1}, \quad \mu=i \kappa_{s}, \\
K_{ \pm} & =\frac{\exp \left[\mp \mu \operatorname{arccosh}\left(h_{0}^{-1}\right)\right]}{\Gamma(1 \pm \mu)} .
\end{aligned}
$$

The specific form of $f_{ \pm}(\xi)$ allows us interpret these functions as non-exponential running waves inside layered superconductor. Indeed, for $1-z \ll 1$ there is an asymptotic expression [13] for Legendre functions:

$$
P_{v}^{\mu}[z] \approx \frac{2^{\mu / 2}}{\Gamma(1-\mu)}(1-z)^{-\mu / 2}
$$

The approximation (15) can be applied for $\tanh \left(\xi_{0}+\xi\right) \approx 1$, i.e. for the external magnetic field that is close to zero $\left(H_{0} \ll H_{c}\right)$ or for the $x$-coordinate deeply inside the superconducting plate. Thus, in the center of the plate $(\xi \ll \delta)$, the functions $f_{ \pm^{\prime}}(\xi)$ take the exponential form,

$$
f_{ \pm^{\prime}}(\xi) \approx \exp \left( \pm i \kappa_{s} \xi\right)
$$

and these functions correspond to the running waves.

Taking into account the obvious relation,

$$
f_{ \pm}(\xi)=-f_{\mp}(-\xi)
$$

and matching $f_{L}(\xi=0)=f_{R}(\xi=0)$ in the center of the plate, we relate the constants of the superpositions (13) and (14):

$$
\tilde{C}^{ \pm}=-C^{\mp}
$$

Finally, we should normalize the constants $C^{ \pm}$in order to get the expression for magnetic field similar to (4):

$$
S^{ \pm}=C^{ \pm} \frac{H_{0}}{1+\kappa_{z}^{2} /\left(1-\Omega^{2} / \gamma^{2}\right)}
$$

Now, the electromagnetic field components are, 


$$
\begin{gathered}
E_{z}^{s}(\xi)=\frac{\Omega+\frac{\kappa_{z}^{2} \gamma^{2} \Omega}{\gamma^{2}-\Omega^{2}}}{i \sqrt{\varepsilon_{s}}}\left[ \pm S^{ \pm} f_{+}( \pm \xi) \pm S^{\mp} f_{-}( \pm \xi)\right], \\
H_{y}^{s}(\xi)=S^{ \pm} f_{+}^{\prime}( \pm \xi)+S^{\mp} f_{-}^{\prime}( \pm \xi) .
\end{gathered}
$$

Here the upper sign corresponds to the right part ( $\xi>0$ ) of the plate and the lower one corresponds to the left part $(\xi<0)$.

If the external dc field tends to zero, the expressions (17) turn out to be harmonic, and the wave transfer through the investigated system could be described by the matrices of passing through the boundaries and free propagation in the medium [4] in a similar way to the dielectric case. Otherwise, the magnetic field $H_{y}(x)$ can be considered as a plane wave superposition only in the center of the plate.

\section{Transfer matrices}

The transfer-matrix $\hat{T}$ that corresponds to the wave transfer through the plate connects the amplitudes of outgoing and incoming waves for the magnetic field $H_{y}(x)$. According to (4):

$$
\left(\begin{array}{l}
R^{+} \\
R^{-}
\end{array}\right)=\hat{T}\left(\begin{array}{l}
L^{+} \\
L^{-}
\end{array}\right)
$$

Since the field in the layered superconductor can be described by exponential functions only in the center, we can present the matrix $\hat{T}$ as $\hat{T}=\hat{T}^{(R)} \hat{T}^{(L)}$, that correspond to the transition from the left boundary $(x=-s / 2)$ to the center $(x=0)$ and from the center $(x=0)$ to the right boundary $(x=s / 2)$, respectively,

$$
\left(\begin{array}{l}
R^{+} \\
R^{-}
\end{array}\right)=\hat{T}^{(R)}\left(\begin{array}{l}
S^{+} \\
S^{-}
\end{array}\right), \quad\left(\begin{array}{l}
S^{+} \\
S^{-}
\end{array}\right)=\hat{T}^{(L)}\left(\begin{array}{l}
L^{+} \\
L^{-}
\end{array}\right) .
$$

The boundary conditions are the matching of the tangential components of the electromagnetic field:

$$
\begin{aligned}
& H_{y}^{s}(-s / 2)=H_{y}^{L}(-s / 2), \quad H_{y}^{s}(s / 2)=H_{y}^{R}(s / 2), \\
& E_{z}^{s}(-s / 2)=E_{z}^{L}(-s / 2), \quad E_{z}^{s}(s / 2)=E_{z}^{R}(s / 2) .
\end{aligned}
$$

In accordance with the expressions for the electromagnetic field (4), (5), and (17), these conditions can be rewritten as:

$$
\begin{aligned}
& \left\{\begin{array}{c}
S^{+} f_{+}^{\prime}(\delta)+S^{-} f_{-}^{\prime}(\delta)=R^{+}+R^{-} \\
S^{+} f_{+}(\delta)+S^{-} f_{-}(\delta)=\eta\left(R^{+}-R^{-}\right)
\end{array}\right. \\
& \left\{\begin{array}{c}
S^{+} f_{-}^{\prime}(\delta)+S^{-} f_{+}^{\prime}(\delta)=L^{+}+L^{-} \\
S^{+} f_{-}(\delta)+S^{-} f_{+}(\delta)=\eta\left(L^{-}-L^{+}\right)
\end{array},\right.
\end{aligned}
$$

where

$$
\eta=\frac{-i k_{d} c \omega_{J} \sqrt{\varepsilon_{s}}}{\Omega^{2} \varepsilon_{d}\left(1+\frac{\kappa_{z}^{2} \gamma^{2}}{\gamma^{2}-\Omega^{2}}\right)} .
$$

Comparing the system of matrix equations (19) and the boundary conditions in form (21), we can obtain the exact expressions for the transfer-matrices $\hat{T}^{(R)}$ and $\hat{T}^{(L)}$ :

$$
\begin{gathered}
\hat{T}^{(R)}=\frac{1}{2}\left(\begin{array}{cc}
+\frac{f_{+}(\delta)}{\eta}+f_{+}^{\prime}(\delta) & +\frac{f_{-}(\delta)}{\eta}+f_{-}^{\prime}(\delta) \\
-\frac{f_{+}(\delta)}{\eta}+f_{+}^{\prime}(\delta) & -\frac{f_{-}(\delta)}{\eta}+f_{-}^{\prime}(\delta)
\end{array}\right), \\
\hat{T}^{(L)}=\frac{1}{2 \operatorname{det} \hat{T}^{(R)}}\left(\begin{array}{cc}
+\frac{f_{+}(\delta)}{\eta}+f_{+}^{\prime}(\delta) & +\frac{f_{+}(\delta)}{\eta}-f_{+}^{\prime}(\delta) \\
-\frac{f_{-}(\delta)}{\eta}-f_{-}^{\prime}(\delta) & -\frac{f_{-}(\delta)}{\eta}+f_{-}^{\prime}(\delta)
\end{array}\right) .
\end{gathered}
$$

Here

$$
f_{ \pm}(\delta) \approx \frac{P_{v}^{\mp \mu}\left[h_{1}\right]}{ \pm \mu K_{ \pm} \exp (\mp \mu \delta)}, \quad f_{ \pm^{\prime}}(\delta) \approx \frac{h_{0}^{2} \frac{\partial}{\partial h_{1}} P_{v}^{\mp \mu}\left[h_{1}\right]}{\mp 2 \mu K_{ \pm} \exp (\mp \mu \delta)},
$$

with $h_{1}=\sqrt{1-h_{0}{ }^{2}}$.

It can be seen, that the matrices $\hat{T}^{(L)}$ and $\hat{T}^{(R)}$ are not mutually inverse. Nevertheless, the product of their determinants is equal to $1, \operatorname{det}\left[\hat{T}^{(L)}\right] \operatorname{det}\left[\hat{T}^{(R)}\right]=1$, therefore, the symmetry of the problem is not broken.

\section{Conclusions}

In this theoretical work, we have modified the transfer-matrix method for TM-polarized electromagnetic waves propagating through a plate of layered superconductor taking into account the interaction of Josephson plasma with an external dc magnetic field. It was shown that although the electromagnetic field inside the plate cannot be described by harmonic (exponential) functions, far from the boundaries, it can be considered as a superposition of a running and reflected waves. Then, for sufficiently thick plate, the transfer-matrices can be obtained analytically in terms of special Legendre functions. The received matrices can be used in the further studies related to the transfer of electromagnetic waves through layered superconductors.

\section{Acknowledgment}

The publication contains the results of studies conducted by President's of Ukraine grant for competitive projects $(\Phi 82 / 233-2019)$. 


\section{References}

1. R. Kleiner, F. Steinmeyer, G. Kunkel, and P. Muller, Phys. Rev. Lett. 68, 2394 (1992).

2. R. Kleiner and P. Muller, Phys. Rev. B 49, 1327 (1994).

3. S. Savel'ev, V. A. Yampol'skii, A. L. Rakhmanov, F. Nori, Rep. Prog. Phys. 73, 026501 (2010).

4. S. S. Apostolov, N. M. Makarov, V. A. Yampol'skii, Phys. Rev. B 97, 075101 (2018).

5. T. N. Rokhmanova, S. S. Apostolov, Z. A. Maizelis, V. A. Yampol'skii, F. Nori, Phys. Rev. B 88, 014506 (2013)

6. T. Rokhmanova, S. S. Apostolov, N. Kvitka, and V. A. Yampol'skii, Low Temp. Phys. 44, No.6, 552 (2018).

7. S. S. Apostolov, Z. A. Maizelis, N. M. Makarov, F. PérezRodríguez, T. N. Rokhmanova, V. A. Yampol'skii, Phys. Rev. B 94, 024513 (2016).

8. B. Ferguson, X-C. Zhang, Nature Mat. 1, 26 (2002).

9. M. Tonouchi, Nature Phot. 1, 97 (2007).

10. P. Markoš, C. M. Soukoulis. Wave Propagation: From Electrons to Photonic Crystals and Left-Handed Materials. Princeton University Press, p. 376 (2008).

11. A. L. Rakhmanov, V. A. Yampolskii, J. A. Fan, F. Capasso, F. Nori, Phys. Rev. B 81, 075101 (2010).

12. V. A. Yampol'skii, D. R. Gulevich, S. Savel'ev, F. Nori, Phys. Rev. B 78, 054502 (2008).

13. H. Bateman, Higher Transcendental Functions [Volumes IIII]. Vol.I. McGraw-Hill Book Company, New York (1953). 